\title{
Case Presentation: a Facial Ulceration in a Patient with Ulcerative Colitis
}

\author{
Andreea GHIDERSA ${ }^{1}$, Ruxandra BABIUC ${ }^{1}$, Lucian NEGREANU ${ }^{7}$
}

\begin{abstract}
We present the case of a patient with severe ulcerative colitis treated with infliximab that was admitted for an extensive facial ulceration located on the left cheek. Pyoderma gangrenosum, bacterial, mycobacterial and fungal infection were taken into account. The patient was diagnosed with a Klebsiella abscess originating from a tooth infection. Infectious complications might arise more frequently in IBD patients treated with anti TNF and adequate diagnosis and therapy is required.
\end{abstract}

Keywords: facial ulceration, ulcerative colitis, infliximab, pyoderma gangrenosum, Klebsiella infection.

\section{Rezumat}

Infecțiile la pacienții cu boli inflamatorii intestinale sunt o complicație redutabilă; sunt frecvent asociate cu anumite terapii precum: administrarea de corticosteroizi, dar și de imunomodulatoare de tipul anti factor de necroză tumorală. Prezentăm cazul unui pacient cu colită ulcerativă, cu afectare severă pancolonică, aflat în tratament cu infliximab care s-a internat ca urmare a apariției unei ulcerații faciale localizate la nivelul lojei submandibulare stângi. În analiza acestui caz au fost luate în considerare manifestările extra-digestive ale bolii inflamatorii intestinale (pyoderma gangrenosum), infecțiile bacteriene, fungice și tuberculoza.

Cuvinte cheie: ulcerație facială, colită ulcerativă, pyoderma gangrenosum, infecție cu Klebsiella.

\section{CASE PRESENTATION}

A 51-year-old male with underlying ulcerative colitis presented to our hospital for a rapidly progressing facial lesion affecting the left cheek (Figure 1) and multiple painful erythematous nodules located predominantly on the chest, left knee and first left metatarsophalangeal joint.

The patient was diagnosed with severe and extensive ulcerative colitis in 2016 and since February 2018 was treated with Infliximab $(5 \mathrm{mg} / \mathrm{kg}$ intravenous perfusion every 8 weeks).

On admission the laboratory analysis showed leukocytosis, neutrophilia, severe iron deficiency anemia and intense inflammatory syndrome, without any other abnormal test results.

The head CT scan showed a 38/21/8mm lesion with important densification of the subcutaneous tissue of the left cheek associated with left cervical pneumatoceles (Figure 2\&3).
' Department of Gastroenterology, Emergency University Hospital, „Carol Davila" University Bucharest, Romania

\section{Corresponding author.}

Ruxandra BABIUC, Department of Gastroenterology, University Emergency Hospital, "Carol Davila" University Bucharest, Romania.

E-mail: ruxandra.babiuc@umfcd.ro 


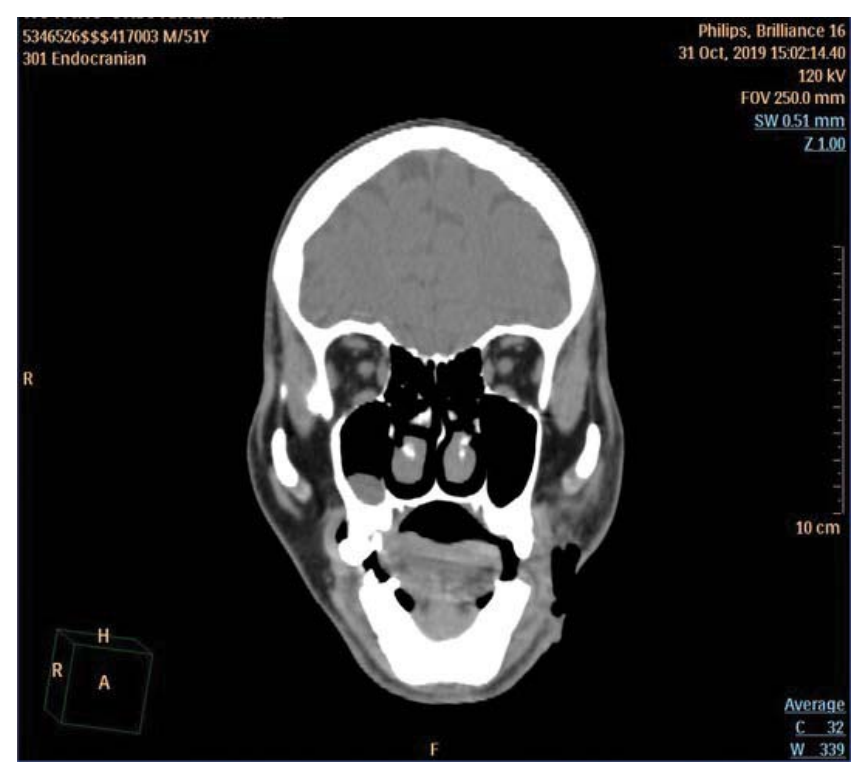

Figure 1.

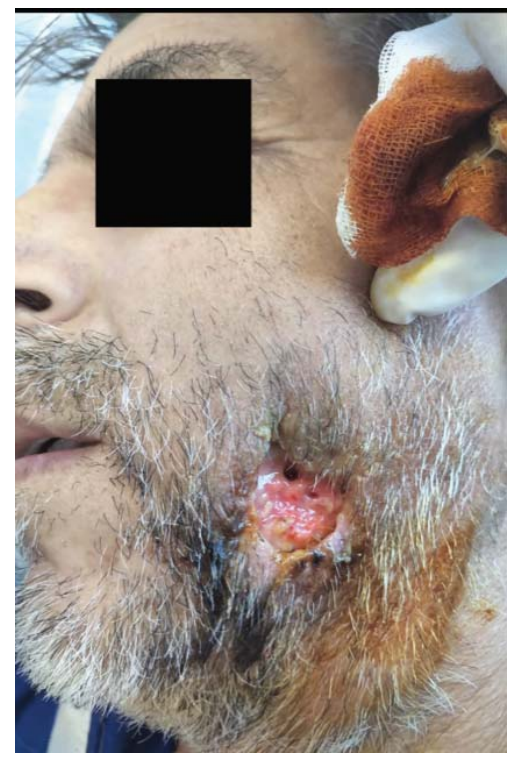

Figure 3.

The patient underwent colonoscopic evaluation which revealed active pancolitis. Also multiple skin biopsies were performed. A skin nodule biopsy showed areas of necrosis with neutrophil debris.

\section{DIAGNOSIS AND EVOLUTION}

Bacterial infection with abscess, tuberculosis, aspergillosis and mucormycosis were taken into account. Also a spinocellular carcinoma and pyoderma gangrenosum were discussed as possible diagnosis.

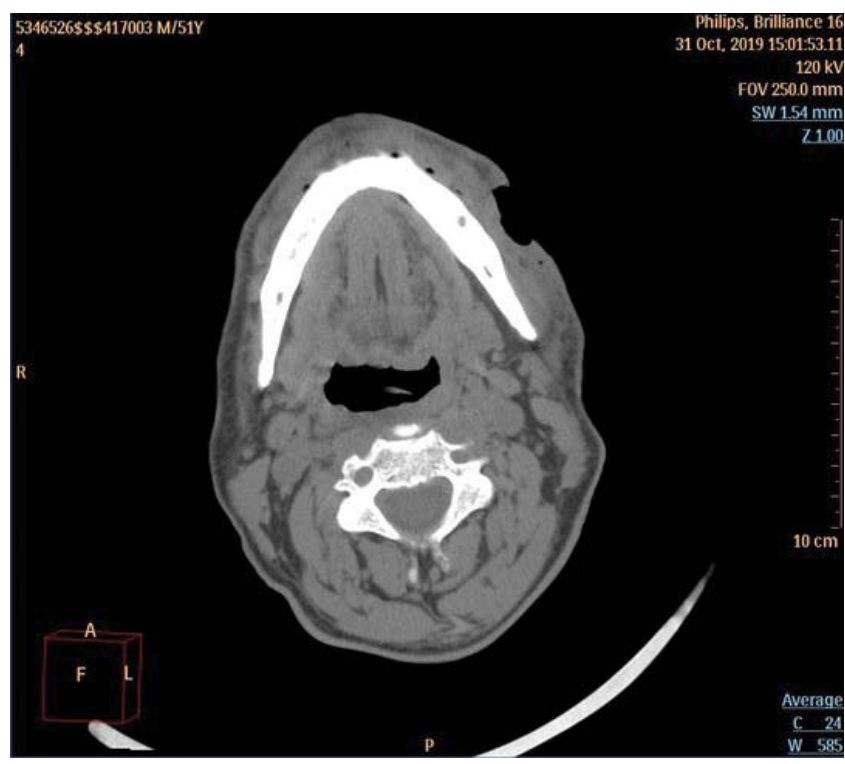

Figure 2.

Following the oral and maxillofacial surgery examination the resulting diagnosis was: abscess in the left submandibular lobe fistulised to the skin. The wound culture revealed growth of a gram negative bacillus, which was later identified as Klebsiella pneumoniae.

Broad spectrum antibiotics were initiated. Daily local toiletry, local antiseptic and bandage were practiced. Subsequently, under loco-regional anesthesia, tooth 36 is extracted, considered to be the cause of infection. Curettage and haemostasis were practiced.

The patient's clinical condition improved, consisting in rapid healing of both skin lesions - subcutaneous nodules and facial ulcer, with closure of the skin defect and remission of purulent secretions, as well as of trismus. The patient was discharged after 3 weeks of antibiotherapy with indication of continuing his treatment with Infliximab. Other complementary blood tests, such as anti TNF-alpha antibodies and anti-TNF trough levels were performed and anti TNF therapy was adjusted.

\section{DISCUSSION}

A wide differential diagnosis should be discussed when talking about a trans mural facial ulceration, especially in an immunocompromised patient. Dermatological adverse events due to anti-TNF alpha drugs may be confused with extra intestinal manifestations (EIMs) of IBD ${ }^{1}$. Pyoderma gangrenosum is the main EIM taken into consideration in this particular case, but the positive cultures and the response to antibiotherapy are pleading against this diagnosis ${ }^{2}$. 
We found a quite similar case with a facial lesion in Crohn's disease patient that turned to be pyoderma gangrenosum ${ }^{3}$. However there are major differences to our case: the lesion was sterile, pyoderma exhibits pathergy with any trauma, including surgical manipulation(not seen in our case). Although biopsy results alone cannot be used to diagnose pyoderma gangrenosum, the histopathology of lesions usually shows significant dermal neutrophilic infiltration with occasional cases showing leukocytoclastic vasculitis, not seen in our patient.

The use of anti-TNF-alpha drugs is associated with an increased risk of infection including colonisation by opportunistic germs such as atypical mycobacterial infection, mucormycosis, blastomycosis, cryptococcossis, sporotrichosis or gummatous syphilis ${ }^{4}$. Other possible diagnosis include Verneuil disease, dental abscess,

\section{References}

1. Moran, G. W., et al. "Dermatological complications of immunosuppressive and anti-TNF therapy in inflammatory bowel disease." Alimentary pharmacology \& therapeutics 38.9 (2013): 1002-1024.

2. Gameiro, A., Pereira, N., Cardoso, J. C., \& Gonçalo, M. (2015). Pyoderma gangrenosum: challenges and solutions. Clinical, cosmetic and investigational dermatology, 8, 285.
Rheumatoid vasculitis, Wegener's granulomatosis and Behcet's syndrome 5 .

Sometimes a „banal” dental abscess can evolve to transmural necrosis and ulceration in an immunocompromised patient, and proper follow up and monitoring should be offered to all IBD patients taking anti TNF therapy.

Compliance with ethics requirements: The authors declare no conflict of interest regarding this article. The authors declare that all the procedures and experiments of this study respect the ethical standards in the Helsinki Declaration of 1975, as revised in 2008(5), as well as the national law. Informed consent was obtained from all the patients included in the study.

3. Huang B, Melmed G, Shih D. Facial Ulceration in a Patient With Crohn's Disease. Gastroenterology 2012; 142 (5):1257-1258

4. Ali, Tauseef, et al. "Clinical use of anti-TNF therapy and increased risk of infections." Drug, healthcare and patient safety 5 (2013): 79.

5. Elston, D., Ferringer, T., Ko, C. J., Peckham, S., High, W. A., \& DiCaudo, D. J. (2013). Dermatopathology E-Book. Elsevier Health Sciences. 
